\title{
Synthesis and Study of Copolymers of Methyl Pheophorbide $a$ and its Copper Complexes with Methyl Methacrylate
}

\author{
Olga I. Nikolaeva, ${ }^{\circledR}$ Yulia V. Romanenko, ${ }^{a}$ Tatiana A. Ageeva, ${ }^{a}$ \\ and Oscar I. Koifman ${ }^{a, b}$
}

\author{
${ }^{a}$ Research Institute for Macro-Heterocyclic Compounds at Ivanovo State University of Chemistry and Technology (ISUCT), \\ Ivanovo. \\ ${ }^{\mathrm{b}}$ Institute for Solutions Chemistry of the Russian Academy of Sciences, Ivanovo \\ @Corresponding author Email: onik@isuct.ru
}

\begin{abstract}
We studied radical polymerization in methyl methacrylate solution with methyl pheophorbide a and its copper complex. We have shown the possibility of controlled synthesis of copolymers with controllable molecular weight characteristics when reaction medium parameters are varied. We have established that the composition of copolymers depends on the comonomer content of the original reaction medium, on the yield and influence of the metal in the porphyrin coordination centre on copolymer properties.
\end{abstract}

Keywords: Monomers, porphyrins, metal complexes, spectra, solutions, copolymerization.

\section{Introduction}

Tetrapyrrole macroheterocyclic compounds and their metallic complexes, including metallic porphyrins and similar substances, are widely distributed in nature in the composition of chlorophylls, cytochromes, certain enzymes, and show promise in various practical applications, also in the synthesis of bioactive substances. The use of natural porphyrins and their metallic complexes in the synthesis of bioactive substances contrasts favourably with the use of synthetic compounds in that the resulting products are considerably less toxic. Today natural metallic porphyrins are widely used as effective catalysts, heat and light stabilizers, diagnostic and medicinal products, organic semiconductors, colouring pigments and dyes etc. In addition, these compounds are studied as ingredients in the design of supra-molecular functional systems comprising porphyrin polymers. ${ }^{[1]}$ The properties of porphyrin polymers are determined not only by the nature and peculiarities of macro-heterocyclic compounds but also the method of including them in the system. There are two methods of obtaining porphyrin-containing polymers, namely, polymer-analogous conversion ${ }^{[1-2]}$ and (co)polymerization of monomers, one of which is porphyrin or a similar substance. ${ }^{[3-8]}$

All chemical conversions of natural porphyrins and their metallic complexes, ${ }^{[9]}$ including polymer-analogous conversions involving tetra-pyrrole macro-heterocyclic compounds are conducted in solutions. ${ }^{[10]}$ Research into the latter's condition in organic solvents enables us to establish the main patterns characterizing the interaction of porphyrins and their metallic complexes with their reaction medium and determine the optimal conditions for reactions involving these compounds. ${ }^{[1]}$ Currently, porphyrin polymers have been synthesized using both natural porphyrin ${ }^{[12]}$ and synthetic porphyrins ${ }^{[5-7]}$ as the base. However, such polymers have hardly been studied. It is therefore necessary to conduct comprehensive research into the nature of the process of obtaining porphyrin polymers in different media, and to determine the influence of solvents and initiators on the reactive ability of (co)monomers and on polymerization and copolymerization process parameters in order to establish the possibility and conditions of purposeful synthesis of copolymers with improved alternation of links and properties suitable for producing new functional polymers.

The purpose of the present investigation was the synthesis and study in solution of copolymers methyl pheophorbide $a$ (MPP) and its cuprous complex (CuMPP, Chart 1) with methyl methacrylate (MMA) of different composition.

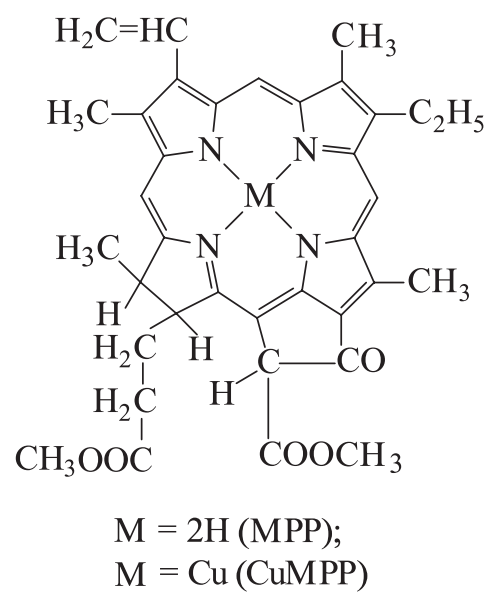

Chart 1. 


\section{Experimental}

MMA was cleansed of stabilizer by shaking in a $10 \% \mathrm{KOH}$ solution, washed with water till a neutral reaction was obtained, dried with $\mathrm{CaCl}_{2}$ and purified by vacuum distillation $(200 \mathrm{~mm}$ mercury pressure) at $63^{\circ} \mathrm{C}$ in the presence of a hydroquinone as an inhibitor to prevent polymerization. ${ }^{[13]}$

As a second comonomer, imparting new properties to the polymers being synthesized, we used methyl pheophorbide $a$ or its cuprous complex, which has a vinyl group at the periphery of its molecule and is characterized by acceptable solubility in organic solvents.

Methyl pheophorbide a was obtained by extraction from Spirulina microalgae. After standing, the extract was evaporated up to $1 / 3$ of its volume and poured into water, while the precipitate was filtered through a celit 545 washable filter, washed with hot water and then hexane, then washed off the filter with acetone and a mixture of acetone and chloroform. The MPP-containing solution was evaporated to remove organic solvents and wiped off with methanol, then filtered and washed in a calculated quantity of methanol and hexane. The precipitate was dried in the air.

The resulting product was then subjected to prolonged purification by chromatography on a column filled with silica gel, using a dichlormethane-ether mixture as an eluent. The degree of purification was monitored by means of thin-layer chromatography. ${ }^{[14]}$

Mass spectrum MALDI-TOF (ditranol) $\mathrm{m} / \mathrm{z}: 607[\mathrm{M}+\mathrm{H}]^{+}$, $629[\mathrm{M}+\mathrm{Na}]^{+}, 645[\mathrm{M}+\mathrm{K}]^{+}$. UV-Vis (chloroform) $\lambda \mathrm{nm}(\lg \varepsilon)$ : 668 (4.63); 610 (3.91); 538 (3.98); 508 (4.00); 413 (4.96). IR (KBr) $v \mathrm{~cm}^{-1}: 3391,2957,2918,2869,1739,1700,1619,1499,1434,1347$, 1204, 1164, 1035, 991, 910, 722, 673, 607.

Methyl pheophorbide $a$ complex with copper was obtained by the interaction of a free ligand with copper acetate(II) in dimethyl formamide at room temperature (Figure 1). ${ }^{[15]}$ After standing, the reaction mass was poured into water, while the precipitate was filtered and washed with water, dried in the air and then chromatographed on a column filled with silica gel, and eluted with chloroform-acetone mixture.

UV-Vis (chloroform) $\lambda \mathrm{nm}$ (lge): 391 (4.77); 413 (5.14), 645(4,6). IR (KBr) $v \mathrm{~cm}^{-1}: 2960,2929,2863,1728,1636,1560$, 1450, 1383, 1283, 1073, 995, 924, 823, 746.

Azobis-iso-butyronitrile (AIBN) and benzoyl peroxide (BP) were used as copolymerization initiators. The first was purified to remove additives by triple recrystallization from ethanol and dried in a vacuum at room temperature to a constant mass. The recrystallised product's purity was determined by its melting point using the standard method in a sealed capillary $\left(\mathrm{T}_{\mathrm{m}}=103^{\circ} \mathrm{C}\right) \cdot{ }^{[13]}$

Benzoyl peroxide was purified by recrystallisation from methanol and dried in a vacuum at room temperature to a constant mass, $\mathrm{T}_{\mathrm{m}}=106^{\circ} \mathrm{C} \cdot{ }^{[13]}$

The solvents used to synthesize copolymers (ethanol, chloroform, dimethyl formamide) were purified using the methods indicated in the references below. ${ }^{[16,17]}$ Tetrahydrofuran (THF) was monitored for the presence of peroxides, traces of which were removed by boiling with a $0.5 \%$ suspension of $\mathrm{CuCl}_{2}$ for 30 minutes, followed by distillation. THF was then dried over $\mathrm{KOH}$ granules, boiled under reflux and distilled over calcium hydride. [16] The physical and chemical characteristics of the purified, distilled solvents conformed to published data. ${ }^{[16,17]}$

Radical copolymerization of MPP with methyl methacrylate and the latter with CuMPP was carried out in tetrahydrofuran contained in previously cleaned and dried glass ampoules, filled with a certain quantity of initiator. Filling with AIBN was followed by filling with MPP (its copper complex), then the required quantity of methyl methacrylate and the same quantity of solvent (THF) were poured through a funnel from a calibrated pipette. Total reaction mixture volume in the ampoule did not exceed 2/3 of the latter's volume. Argon was blown through the cooled ampoules to remove oxygen. After cooling and sealing the ampoules were shaken until the initiator (MPP or its copper complex) was completely dissolved and a homogeneous solution obtained, and then placed in a thermostat at $60^{\circ} \mathrm{C}$. When the required time had elapsed, the ampoules were removed from the thermostat and cooled. Polymer formation was monitored visually, according to increasing viscosity of the reactive mixture. To separate the polymer, the contents of the opened ampoules was dissolved in THF, and the resulting solution was precipitated with triple its volume of ethanol. Chemically non-bonded MPP (its metallic complex) was removed by repeatedly precipitating products from THF into ethanol until no MPP (CuMPP) was present in the liquid phase, and by extraction lasting many hours, using a copolymer selective solvent, namely, ethyl alcohol, after which the copolymers were dried to a constant mass at $50^{\circ} \mathrm{C}$.

Number-average $\left(\mathrm{M}_{\mathrm{n}}\right)$ and weight-average $\left(\mathrm{M}_{\mathrm{w}}\right)$ molecular weight of copolymers was determined by means of gel-penetrating chromatography using a LC-20 "Prominence" ("Shimadzu") liquid chromatograph equipped with two columns $\left(\mathrm{GMH}_{\mathrm{HR}}-\mathrm{L} 30\right.$ $\mathrm{cm} \cdot 7.8 \mathrm{~mm}$; G2500-HHR $30 \mathrm{~cm} \cdot 7.8 \mathrm{~mm}$ ), at $40^{\circ} \mathrm{C}$. Chloroform was used as a solvent, with a flow speed of $0.75 \mathrm{ml} / \mathrm{min}$. The column system was calibrated to polystyrene standards with narrow molecular weight distribution $\left(M_{w} / M_{n} \leq 1,05\right)$.

Electronic absorption spectrum of porphyrin and its metallic complex, and the resulting porphyrin polymers was measured in MMA, THF and their mixtures, also in chloroform using a Lambda 20 Perkin-Elmer spectrophotometer over a range of 300-750 $\pm 1,0$

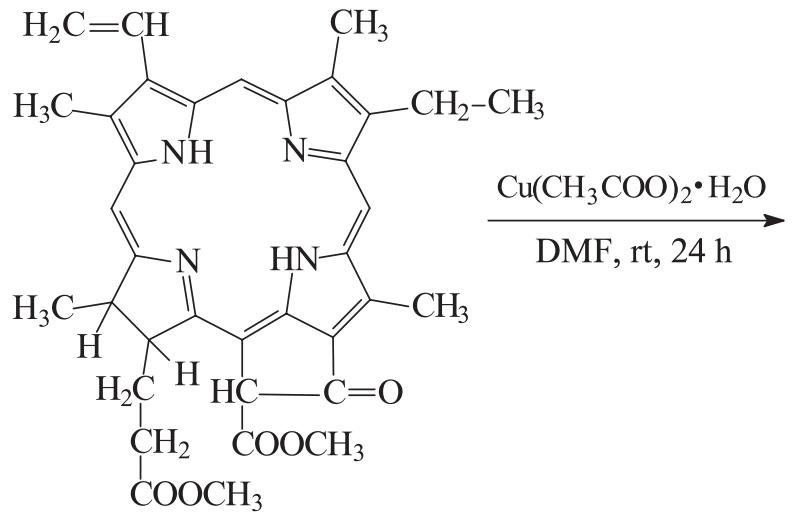

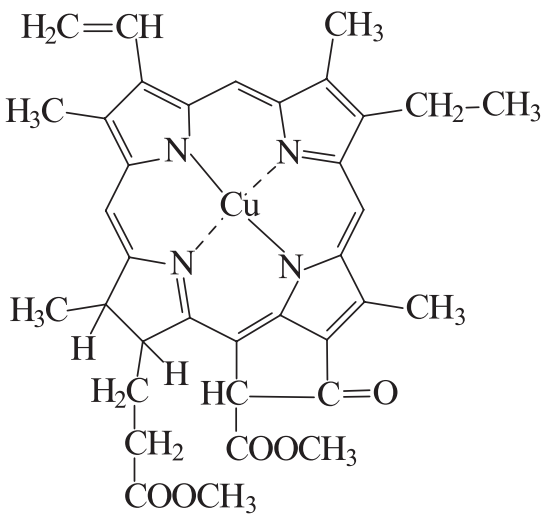

Figure 1. 
$\mathrm{nm}$. Measurement was carried out in standard quartz cells of 1.0 cm thickness.

The composition of the synthesized copolymers was determined by elemental analysis using a FlashEA 1112 analyzer.

Infrared spectra of copolymers was registered using an Avatar 360 FT-IR ESP infrared Fourier spectrometer over a range of 3500$400 \mathrm{~cm}^{-1}$, with film supported by T1Br-TII mixed crystal.

\section{Results and Discussion}

Since a metallic complex's structure determines the nature of its behaviour in various chemical processes taking place in solutions, we first determined the solubility of the copper complex in tetrahydrofuran, methyl methacrylate and their mixtures $(1: 1)$ at $25^{\circ} \mathrm{C}$ and $60^{\circ} \mathrm{C}$, as well as free MPP. ${ }^{[18]}$ This temperature range was chosen for our purpose because many syntheses involving chlorophyll derivatives are performed at temperatures of up to $60^{\circ} \mathrm{C}$; at higher temperatures these compounds are highly vulnerable to destruction by oxidation. ${ }^{[19]}$

Copper complex solubility was determined by isothermal saturation of the solution, with spectrophotometric control of the level of porphyrin and its complex. ${ }^{[20,21]}$ The sample was dissolved till maximum optical density of the resulting solution was achieved, while retaining the bottom phase and nature of the electronic spectrum of porphyrin absorption. Their solubility $(S)$ was calculated from the maximum optical density of the metallic complex solution. Solubility values $(\mathrm{mol} / \mathrm{l})$ were determined in identical conditions. The experimental data in Table 1 are compared with those for free MPP.

Analysis of the results shows that MMP is twice as soluble in THF-MMA mixture than in methyl methacrylate $(0.0168 \mathrm{~mol} / \mathrm{l})$, but less so than in THF. Transition from porphyrin ligand to its $\mathrm{Cu}^{\mathrm{II}}$ complex reduces solubility in THF 2.5 times at $25^{\circ} \mathrm{C}$ и $60^{\circ} \mathrm{C}$ and 1.5 times in a tetrahydrofuranmethyl methacrylate mixture at $60^{\circ} \mathrm{C}$. However, solubility of the metal complex of methyl pheophorbide $a$ in MMA is more than twice as high both at $25^{\circ} \mathrm{C}$ and $60^{\circ} \mathrm{C}$ than solubility of non-metallic porphyrin.

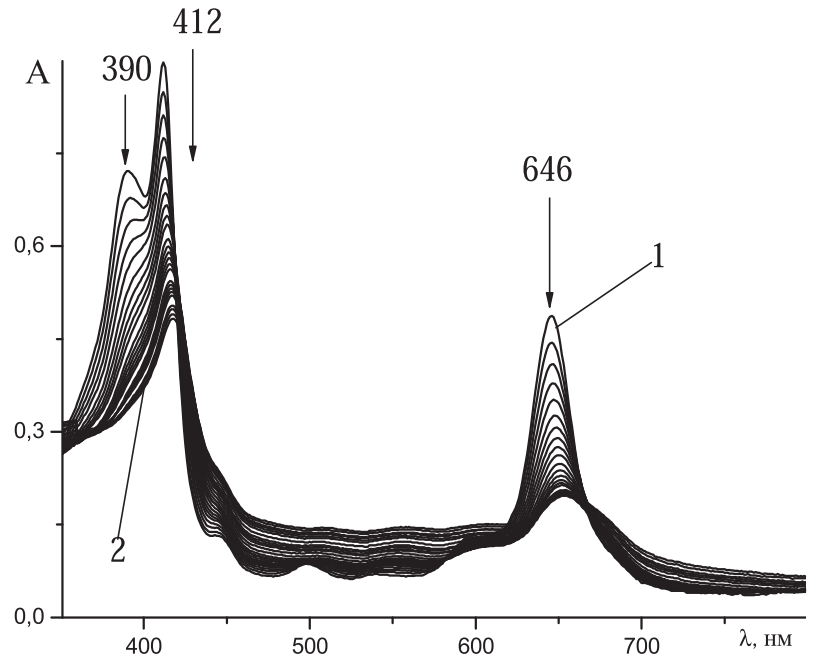

Figure 2. Changes in electronic absorption spectra for CuMPP $\left(1.01 \cdot 10^{-5} \mathrm{~mol} / \mathrm{l}\right)$ when oxidized with benzoyl peroxide $\left(1.01 \cdot 10^{-3}\right.$ $\mathrm{mol} / \mathrm{l})$ in chloroform at $55^{\circ} \mathrm{C}: 1$ - initial CuMPP spectrum in chloroform; 2- spectrum after completion of reaction (after $2 \mathrm{~h}$ ).

Stability of metallic porphyrin in the reaction medium and in the presence of radical polymerization initiators was determined by studying the interaction of MPP and its metallic complex with benzoyl peroxide and AIBN using a spectrophotometric method in a thermostatically controlled chamber, with a temperature range of $35-55^{\circ} \mathrm{C}$. Interaction of MPP and CuMPP with benzoyl peroxide and AIBN in a chloroform medium is accompanied by characteristic spectral changes (Figures 1,2).

With initiator concentrations of $2.03 \cdot 10^{-4}-1.01 \cdot 10^{-3}$ $\mathrm{mol} / \mathrm{l}$ for benzoyl peroxide and $3.06 \cdot 10^{-4}-1.02 \cdot 10^{-3} \mathrm{~mol} / \mathrm{l}$ for AIBN (20-100-fold excess), we noticed the eventual disappearance of the absorption band at $668 \mathrm{~nm}$ for MPP and $646 \mathrm{~nm}$ for CuMPP, and a fall in the Soret band, indicating macrocycle destruction. At $55-45^{\circ} \mathrm{C}$ destruction of porphyrins in the presence of benzoyl peroxide occurs significantly faster, whereas at lower temperatures methyl

Table 1. Solubility $(S)$ and band position in electronic absorption spectra for methyl pheophorbide $a$ and its $\mathrm{Cu}$ complex.

\begin{tabular}{|c|c|c|c|c|c|c|c|}
\hline \multirow{2}{*}{ Solvent } & \multicolumn{2}{|c|}{$S \cdot 10^{2}, \mathrm{~mol} / \mathrm{l}$} & \multicolumn{5}{|c|}{$\lambda_{\max }, \mathrm{nm}(\varepsilon)$} \\
\hline & $25^{\circ} \mathrm{C}$ & $60^{\circ} \mathrm{C}$ & I & II & III & \multicolumn{2}{|c|}{ Soret } \\
\hline THF & 4.83 & 13.32 & $\begin{array}{c}667.3 \\
(44000)\end{array}$ & $\begin{array}{c}609.1 \\
(8750)\end{array}$ & $\begin{array}{c}534.6 \\
(10580)\end{array}$ & $\begin{array}{c}505.7 \\
(11980)\end{array}$ & $\begin{array}{c}410.9 \\
(92410)\end{array}$ \\
\hline MMA & 1.68 & 4.20 & $\begin{array}{c}667.1 \\
(30870)\end{array}$ & $\begin{array}{c}609.1 \\
(5980)\end{array}$ & $\begin{array}{c}534.7 \\
(7080)\end{array}$ & $\begin{array}{c}505.8 \\
(8010)\end{array}$ & $\begin{array}{c}411.0 \\
(63090)\end{array}$ \\
\hline MMA:THF (1:1) & 3.09 & 9.05 & $\begin{array}{c}667.9 \\
(42220)\end{array}$ & $\begin{array}{c}609.2 \\
(7680)\end{array}$ & $\begin{array}{c}534.6 \\
(9270)\end{array}$ & $\begin{array}{c}505.8 \\
(10720)\end{array}$ & $\begin{array}{c}410.3 \\
(85500)\end{array}$ \\
\hline \multicolumn{8}{|c|}{ For CuMPP } \\
\hline THF & 1.9 & 4.75 & $\begin{array}{c}645.9 \\
(45500)\end{array}$ & $\begin{array}{c}544.3 \\
(7031)\end{array}$ & $\begin{array}{c}500.0 \\
(7904)\end{array}$ & $\begin{array}{c}395.2 \\
(62953)\end{array}$ & $\begin{array}{l}412.79 \\
(79892)\end{array}$ \\
\hline MMA & 3.92 & 9.0 & $\begin{array}{c}645.0 \\
(47900)\end{array}$ & $\begin{array}{c}541.8 \\
(8609)\end{array}$ & $\begin{array}{c}498.3 \\
(10230)\end{array}$ & $\begin{array}{c}392.7 \\
(68900)\end{array}$ & $\begin{array}{c}411.8 \\
(86570)\end{array}$ \\
\hline MMA:THF(1:1) & 2.75 & 5.75 & $\begin{array}{c}645.7 \\
(45400)\end{array}$ & $\begin{array}{c}544.1 \\
(6193)\end{array}$ & $\begin{array}{c}500.8 \\
(7231)\end{array}$ & $\begin{array}{c}394.1 \\
(63453)\end{array}$ & $\begin{array}{c}412.3 \\
(81005)\end{array}$ \\
\hline
\end{tabular}


pheophorbide $a$ and its cuprous complex are quite stable in the presence of both initiators.

At concentrations of benzoyl peroxide or AIBN taken in equimolecular ratio and with a 10-15 fold initiator excess, the porphyrin-initiator system is quite stable, without destruction of the macrocycle even at $55^{\circ} \mathrm{C}$. Clearly, the formation of an isoporphyrin structure, as distinct from synthetic porphyrins ${ }^{[22]}$ does not occur spectrally in the cases of MPP and CuMPP.

Since ligands and complexes are destroyed in approximately the same period of time, it may be concluded that the presence of metal in the macrocycle's coordinating cavity does not lead to increased molecular stability.

Using the data in Table 2, we have selected optimal conditions for copolymerization of CuMPP and methyl methacrylate (similar to those for MPP and MMA) in accordance with Chart 2.

The products resulting from copolymerization were identified by electronic spectroscopy, infrared spectroscopy and elemental analysis.

In general, electronic absorption spectra for the obtained copolymers of copper complex of MPP $a$ and MMA are similar in character, which may serve to confirm the presence of metallic porphyrin fragments in the composition of the synthesized compounds. However, when comparing spectra for solutions of cuprous complex of MPP $a$ and copolymers in tetrahydrofuran that are equally concentrated as regards their metallic complex, in the case of porphyrin-containing copolymers we observe a $8-9 \mathrm{~nm}$ hypsochromic shift of the $1^{\text {st }}$ absorption band, and a slight hypsochromic shift of the Soret band relative to the absorption band for monomeric metallic porphyrin. In the case of spectra for solutions of free ligand and copolymers, both in tetrahydrofuran and in dimethylformamide that are equally concentrated as regards porphyrin, in porphyrin-containing copolymers we observe a 5-7 nm hypsochromic shift of the $1^{\text {st }}$ absorption band, and also a slight hypsochromic shift of the Soret band relative to the absorption band for monomeric porphyrin. This is evidently related to the altered electronic structure of the metallic complex of methyl pheophorbide $a$ due to opening of the $\mathrm{C}=\mathrm{C}$ bond participating in the copolymer formation process. Similar spectral changes are observed in electronic absorption spectra during hydration of the double $\mathrm{C}=\mathrm{C}$ bond of methyl pheophorbide $a$. $^{[23]}$

The composition of the copolymers was determined spectrophotometrically according to optical density at the peak of the $1^{\text {st }}$ absorption band for cuprous complex of methyl pheophorbide $a$, making allowance for the insignificant influence of the polymer environment on its extinction coefficients. The quantity of porphyrin attached to the carrier polymer is usually assessed by using the value called the degree of molar immobilization (MID), which determines the number of immobilized porphyrin moles per 100 moles of elementary carrier polymer units. ${ }^{[24]}$ Electro-<smiles>C=C(C)C(=O)OC</smiles>

Chart 2.

Table 2. Conditions for copolymerization of copper complex of methyl pheophorbide $a$ and methyl methacrylate.

\begin{tabular}{|c|c|c|c|c|c|}
\hline $\begin{array}{c}\text { Initial CuMPP:MMA } \\
\text { weight ratio } \\
\end{array}$ & $\begin{array}{c}\text { MMA concentration } \\
C \cdot 10^{3}, \mathrm{~mol} / 1 \\
\end{array}$ & $\begin{array}{l}\text { Copolymerisation } \\
\text { temperature } \mathrm{T},{ }^{\circ} \mathrm{C}\end{array}$ & $\begin{array}{c}\text { Initiator quantity, } \\
\% \\
\end{array}$ & $\begin{array}{l}\text { Reaction time, } \\
\mathrm{h}\end{array}$ & $\begin{array}{c}\text { Copolymer yield, } \\
\% \\
\end{array}$ \\
\hline 1:122 (Cp1) & 4.68 & \multirow{4}{*}{60} & \multirow{4}{*}{0.5} & \multirow{4}{*}{8} & 31 \\
\hline 1:61 (Cp2) & 4.68 & & & & 36 \\
\hline 1:31(Cp3) & 4.68 & & & & 62 \\
\hline 1:23 (Cp4) & 4.68 & & & & 57 \\
\hline $1: 61(\mathrm{Cp} 2 *)$ & 6.24 & \multirow{3}{*}{60} & \multirow{3}{*}{0.5} & \multirow{3}{*}{8} & 84 \\
\hline $1: 31\left(\mathrm{Cp} 3^{*}\right)$ & 6.24 & & & & 74 \\
\hline $1: 23(\mathrm{Cp} 4 *)$ & 6.24 & & & & 40 \\
\hline
\end{tabular}

*-without oxygen 
nic absorption peaks for MPP, CuMPP and the corresponding copolymers in THF, also extinction coefficients $(\varepsilon)$ for free ligand and metallic porphyrin are given in Table 3.

Table 4 shows initial monomer weight ratios and molecular weight characteristics of the obtained copolymers.

The data in Table 4 show that with increased levels of methyl pheophorbide $a$ or its copper complex in the initial reaction medium the number of MPP or CuMPP links increases. Number-average and weight-average molecular weights of the synthesized copolymers decrease with increased levels of MPP or CuMPP in the initial reaction medium (Table 4), which is evidently related to increasing participation of radicals, both of porphyrin and its metallic complex, in bimolecular breaking reactions, including significant steric obstacles. The observed chain break (more commonly manifested in systems containing metallic complexes), is probably due to intramolecular electron transfer. ${ }^{[26,27]}$ The polydispersity parameter $\left(\mathrm{P}_{\mathrm{d}}\right)$ for nonmetallic porphyrin is within the range of $1.35 \div 1.5$, while for $\mathrm{Cu}$ complex of methyl pheophorbide $a$ it is $1.6 \div 2.4$ (as determined by using narrowly fractioned samples).

In the case of lower MMA concentrations $\left(4.68 \cdot 10^{-3} \mathrm{~mol} / \mathrm{l}\right)$ in the reaction medium, a higher copolymer yield is observed with increased CuMPP concentrations. At MMA concentrations of $6.24 \cdot 10^{-3} \mathrm{~mol} / \mathrm{l}$, medium viscosity increases in a shorter period of time -4 hours and more, with increased levels of $\mathrm{Cu}$ complex of methyl pheophorbide $a$ in the reaction medium (Table 2). It has been suggested in the available literature, ${ }^{[26,27]}$ that where metallic porphyrins are present, there is a catalytic transfer of the chain to the monomer due to coupled reactions of dehydration of the growing radical and monomer hydration. Both copper and cobalt complexes can be components of an initiating system. ${ }^{[28]}$

Like the spectral method, the method of elemental analysis enables us to determine the composition of copolymers thanks to the presence of nitrogen atoms in the

Table 3. Position of absorption peaks for solutions of MPP, CuMPP and their copolymers (Cp) in THF.

\begin{tabular}{|c|c|c|c|c|c|c|c|}
\hline \multirow{2}{*}{ Compound } & \multirow{2}{*}{$\begin{array}{l}\text { Degree of molar immobilization } \\
\text { of metallocomplex, mol \% }\end{array}$} & \multirow[b]{2}{*}{ I } & \multirow[b]{2}{*}{ II } & \multirow[b]{2}{*}{ III } & \multicolumn{3}{|c|}{$\lambda_{\max }, \mathrm{nm}(\varepsilon)$} \\
\hline & & & & & IV & \multicolumn{2}{|c|}{ Soret } \\
\hline MPP & - & $\begin{array}{c}667.3 \\
(43996)\end{array}$ & $\begin{array}{c}609.1 \\
(8750)\end{array}$ & $\begin{array}{c}534.6 \\
(10573)\end{array}$ & $\begin{array}{c}505.7 \\
(11975)\end{array}$ & \multicolumn{2}{|c|}{$\begin{array}{c}410.9 \\
(92406)\end{array}$} \\
\hline$(\mathrm{Cp} 1)$ & 0.40 & 660.0 & 603.7 & 532.1 & 502.8 & \multicolumn{2}{|c|}{407.0} \\
\hline$(\mathrm{Cp} 2)$ & 0.50 & 660.0 & 603.4 & 532.1 & 502.5 & \multicolumn{2}{|c|}{407.0} \\
\hline (Cp3) & 0.83 & 660.0 & 603.2 & 532.1 & 502.8 & \multicolumn{2}{|c|}{407.1} \\
\hline (Cp4) & 1.01 & 660.0 & 603.8 & 532.1 & 502.4 & \multicolumn{2}{|c|}{407.0} \\
\hline$(\mathrm{Cp} 2 *)$ & 0.58 & 660.4 & 603.8 & 532.4 & 502.8 & \multicolumn{2}{|c|}{407.0} \\
\hline$(\mathrm{Cp} 3 *)$ & 1.01 & 660.1 & 603.5 & 532.3 & 502.7 & \multicolumn{2}{|c|}{407.1} \\
\hline$(\mathrm{Cp} 4 *)$ & 1.45 & 660.0 & 603.6 & 532.4 & 502.9 & \multicolumn{2}{|c|}{407.1} \\
\hline CuMPP & - & $\begin{array}{c}645.9 \\
(45500)\end{array}$ & $\begin{array}{c}544.3 \\
(7031)\end{array}$ & $\begin{array}{c}500.0 \\
(7904)\end{array}$ & & $\begin{array}{c}395.2 \\
(62953)\end{array}$ & $\begin{array}{c}412.79 \\
(79892)\end{array}$ \\
\hline$(\mathrm{Cp} 1)$ & 0.03 & 638.5 & 542.2 & 497.1 & & 391.7 & 410.5 \\
\hline$(\mathrm{Cp} 2)$ & 0.18 & 637.3 & 544.3 & 498.0 & & 392.5 & 410.0 \\
\hline (Cp3) & 0.21 & 638.2 & 543.1 & 498.6 & & 392.5 & 409.7 \\
\hline (Cp4) & 0.20 & 638.1 & 542.8 & 498.0 & & 393.0 & 409.9 \\
\hline$(\mathrm{Cp} 2 *)$ & 0.13 & 637.8 & 543.0 & 498.8 & & 393.1 & 409.8 \\
\hline$(\mathrm{Cp} 3 *)$ & 0.20 & 638.5 & 545.0 & 498.2 & & 395.2 & 409.9 \\
\hline$(\mathrm{Cp} 4 *)$ & 0.40 & 638.1 & 545.0 & 499.0 & & 393.1 & 410.0 \\
\hline
\end{tabular}

Table 4. Molecular weight characteristics of obtained copolymers.

\begin{tabular}{|c|c|c|c|c|c|c|}
\hline \multirow{2}{*}{ Copolymer (Cp) } & \multicolumn{2}{|c|}{ Copolymer level, mol\% } & \multicolumn{2}{|c|}{$\mathrm{M}_{\mathrm{n}} \cdot 10^{-3}$} & \multicolumn{2}{|c|}{$\mathrm{M}_{\mathrm{w}} \cdot 10^{-3}$} \\
\hline & CuMPP & MPP * & CuMPP & MPP * & CuMPP & MPP * \\
\hline$(\mathrm{Cp} 1)$ & 0.03 & 0.40 & 41 & 61 & 100 & 79 \\
\hline$(\mathrm{Cp} 2)$ & 0.18 & 0.50 & 52 & 73 & 108 & 86 \\
\hline$(\mathrm{Cp} 3)$ & 0.21 & 0.83 & 64 & 74 & 112 & 84 \\
\hline$(\mathrm{Cp} 4)$ & 0.20 & 1.01 & 61 & 55 & 100 & 75 \\
\hline$(\mathrm{Cp} 2 *)$ & 0.13 & 0.58 & 69 & 94 & 131 & 141 \\
\hline$\left(\mathrm{Cp} 3^{*}\right)$ & 0.20 & 1.01 & 60 & 91 & 112 & 134 \\
\hline$\left(\mathrm{Cp} 4^{*}\right)$ & 0.40 & 1.45 & 41 & 80 & 82 & 120 \\
\hline
\end{tabular}

*- previously obtained data ${ }^{[18,25]}$ 
Table 5. Composition of CuMPP and MMA copolymers by elemental analysis.

\begin{tabular}{ccccccccc}
\hline $\begin{array}{c}\text { Composition of CuMMA-MMA } \\
\text { monomer mixture, weight \% }\end{array}$ & $\mathrm{N}$ & $\mathrm{C}$ & $\mathrm{H}$ & $\mathrm{O}$ & $\mathrm{N}$ & $\mathrm{C}$ & $\mathrm{H}$ & $\mathrm{O}$ \\
\hline $1: 122$ & 0.094 & 60.05 & 7.97 & 31.779 & 0.113 & 59.24 & 8.567 & 31.973 \\
$1: 61$ & 0.660 & 60.37 & 7.80 & 30.423 & 0.619 & 59.45 & 7.94 & 31.244 \\
$1: 31$ & 0.790 & 60.45 & 7.75 & 30.110 & 0.747 & 59.49 & 8.245 & 30.618 \\
$1: 23$ & 0.700 & 60.39 & 7.78 & 30.339 & 0.625 & 59.61 & 8.304 & 30.670 \\
$1: 61$ & 0.530 & 60.30 & 7.84 & 30.729 & 0.519 & 59.48 & 8.159 & 31.241 \\
$1: 31$ & 0.770 & 60.43 & 7.76 & 30.162 & 0.761 & 59.43 & 7.989 & 30.942 \\
$1: 23$ & 1.350 & 60.76 & 7.58 & 28.777 & 1.185 & 59.38 & 7.909 & 29.991 \\
\hline
\end{tabular}

cuprous complex of methyl pheophorbide $a$, absent in methyl methacrylate (Table 5).

The results of our experiments, as given in Table 5, agree with theoretically calculated data. The minor discrepancies regarding elements $\mathrm{C}$ and $\mathrm{H}$ may be explained by the fact that the process of decomposition is considerably harder for polymers than for low-molecule organic compounds, starting with degradation to the state of low molecule species, which then interact with oxygen.

To confirm the structure and composition of CuMPP and MMA copolymers we used IR spectroscopy as well as elemental analysis.

Infrared spectra of synthesized copolymers show absorption bands typical for initial comonomers. The principal information is carried by signals located in the range of 1500-1800 $\mathrm{cm}^{-1}$. Infrared spectra of CuMPP and MMA copolymers show new bands in the range of 1550-1650 $\mathrm{cm}^{-1}$, characterising carbonyl vibrations, the intensity of which increases with increased CuMPP in the resulting products as compared with the spectrum for methyl methacrylate.

Intensification is particularly observed in bands $\mathrm{C}_{\mathrm{a}} \mathrm{C}_{\mathrm{m}}$ (vibrations of around $1600 \mathrm{~cm}^{-1}$ ). According to data presented in the cited literature, ${ }^{[29]}$ the $1624-1634 \mathrm{~cm}^{-1}$ band (the strongest in the infrared porphyrin spectrum), belongs to $\gamma$ vibrations of $\delta$ - methine bridges both for porphyrin itself ${ }^{[18]}$ and its metallic complex. Greater intensity of this band indicates increased levels of the cuprous complex of methyl pheophorbide $a$ in the copolymer's composition. The infrared spectroscopic method thus shows that the $\mathrm{Cu}$ complex of methyl pheophorbide $a$ is among the copolymer's components.

Analysis of our results enables us to conclude that the introduction of methyl pheophorbide $a$ or its $\mathrm{Cu}$ complex into a polymer chain significantly influences the optical and molecular weight characteristics of the resulting products. The presence of metal in the coordination centre of porphyrin influences both the copolymerization process and the characteristics of the resulting products. This is clearly related to the formation of the specific CuMPP-MMA complex. Therefore, by varying the conditions of copolymer synthesis and the comonomer ratio, using solvents, the reactive ability of monomers may be purposefully changed and (co)polymers produced with definite molecular weight characteristics and structure.

Acknowledgments. This study was carried out with the financial support of grants from the Russian Foundation for
Basic Research (No. 11-03-01000, 12-03-01014) and the Russian Federation President (support for higher educational institutions, No. 3993.2012.3).

\section{References}

1. Koifman O.I., Ageeva T.A. Porfirinpolimery [Porphyrin Polymers]. Moskva: IFML. 2006. 194 p.(in Russ.).

2. Koifman O.I., Ageeva T.A. Vysokomol. Soedin. 2004, 46, 2187-2215 (in Russ.).

3. Monakov Y.B., Koifman O.I. Uspekhi khimii porfirinov [Advances in Porphyrin Chemistry] (Golubchikov O.A., Ed.). St. Petersburg: NII Khimii SPbGU, Vol. 5, p. 293 (in Russ.).

4. Wöhrle D. J. Porphyrins Phthalocyanines 2000, 4, 418-424.

5. Pomogailo A.D., Bravaya N.M., Razumov V.F., Voloshanovsky I.S., Kitsenko N.F., Berezovsky V.V., Kusaev A.I., Ivanchenko A.G. Izv. RAN., Ser. Khim. 1996, 12, 2922-2929.

6. Pomogailo A.D., Razumov V.F., Voloshanovskii I.S. J. Porphyrins Phthalocyanines 2000, 4, 45-64.

7. Razumov V.F., Ivanchenko A.G., Pomogailo A.D. Optika $i$ Spektroskopiya 1998, 84, 741-746 (in Russ.).

8. Zenkevich E.I., Martin J., Borczyskowski C.V., Ageeva T.A., Titov V.A., Knyukshto V.N. Macroheterocycles 2008, 1, 5967.

9. Nikolaeva I.A., Morozov Y.V., Zavyalova M.G., Novikov R.A., Tkachev Y.V., Timofeyev V.P., Misharin A.Y., Ponomarev G.V. Macroheterocycles 2010, 3, 150-156.

10. Ageeva T.A., Nikolaeva O.I., Koifman O.I. Izv. Vyssh. Ucheb. Zaved., Khim. Khim. Tekhnol. 2004, 47(5), 91-101 (in Russ.).

11. Berezin M.B. Termokhimiya sol'vatacyii khlorofilla $b$ rodstvennukh soedinenyi [Thermochemistry of Solvation of Chlorophyll b Relative Compounds]. Moskva: Krasand. 2008, 256 p. (in Russ.).

12. Nishide H., Shinohara K., Tsuchida E. J. Polym. Sci., Polym. Chem. Ed. 1981, 19, 1109-1117.

13. Toroptseva A.M., Belogorodskaya K.V., Bondarenko V.M. Laboratornyi praktikum po khimii $i$ tekhnologyi vysokomolekulyarnykh soedinenii [Laboratory Practice Book on Chemistry and Technology of High Molecule Compounds]. Leningrad: Khimiya. 1972. 416 p. (in Russ.).

14. Nifantiev N.E., Yashunsky D.V. US Patent № 6777402, 2004.

15. Porphyrins and Metalloporphyrins (Smith K.M., Ed.). New York: Elsevier, 1975, $590 \mathrm{p}$.

16. Gordon A., Ford R. Sputnik Khimika [Chemists Companion]. Moskva: Mir. 1976, 541 p. (in Russ.).

17. Weisberg A., Proscauer E., Riddik J., Tups E. Organicheskie rastworiteli. Fizicheskie svoistva i metody ochistki. Moskva: III. 1958, 518 pp. (in Russ).

18. Nikolaeva O.I., Ageeva T.A., Rashidova S.T., Glazkova M.F., Koifman O.I. Izv. Vyssh. Uchebn. Zaved., Khim. Khim. Tehnol. 2010, 53(12), 64-69 (in Russ.). 
19. Jaquinod L. In: The Porphyrin Handbook (Kadish K.M., Smith K.M., Guilard R., Eds.). 2000, Vol. 1, 201-238.

20. Koifman O.I., Nikiktina G.E., Berezin B.D. Zh. Fiz. Khim. 1982, 56, 737-739 (in Russ.).

21. Sverdlova O.V. Elektronnye spektry $v$ organicheskoi khimii [Electronic Spectra in Organic Chemistry]. 1973, 248 p. (in Russ.).

22. Glazkova M.E., Ageeva T.A., Nikolayeva O.I., Rumyantseva Y.V., Koifman O.I. Izv. Vyssh. Uchebn. Zaved., Khim. Khim. Tehnol. 2011, 54, 104-108 (in Russ.).

23. Fischer H., Orih H. Die chemie des pyrrols. Bd2. Leipzig: Akademische verlagsgesellschaft. M.B.H. 1940, 478 p.

24. Govorov A.G., Korzhenevsky A.B., Koifman O.I. Izv. Vyssh. Uchebn. Zaved., Khim. Khim. Tehnol. 1993, 36(9), 86-90 (in Russ.).
25. Nikolaeva O., Ageeva T., Koifman O. J. Porphyrins Phthalocyanines 2008, 12, 437.

26. Razumov V.F., Ivanchenko A.G., Pomogailo Y.D., Voloshansky I.S., Kusaev A.I. Vysokomol. Soedin., Ser. B 1997, 39, 2046-2050 (in Russ.).

27. Pomogailo A.D., Razumov V.F., Voloshanovskii I.S. J. Porphyrins Phthalocyanines 2000, 4, 45-64.

28. Islamova R.M., Sadykova G.R., Ionova I.A., Sirbu S.A., Koifman O.I., Monakov Y.B. Izv. Vyssh. Uchebn. Zaved., Khim. Khim. Tehnol. 2008, 51(3), 65-68 (in Russ.).

29. Soloviev K.N., Gladkov L.L., Starukhin A.S., et al. Spektroskopiya porfrinov: kolebatel'nye sostoyaniya [Spectroscopy of Porphyrins: Vibrational State]. Minsk: Nauka i Tekhika, 1985, 415 p. (in Russ.).

Received 09.06.2012

Accepted 19.06.2012 